The research of the economic attitudes of Ukrainian youth: theoretical and practical aspects

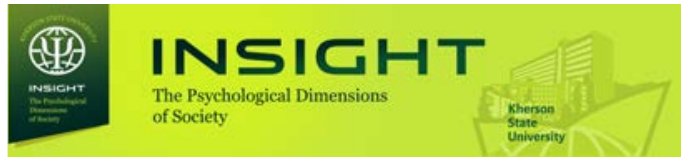

DOI: 10.32999/2663-970X/2021-5-8

Link article (Style APA): Orap M. O. \& Kalba Ya. Ye. (2021). The research of the economic attitudes of Ukrainian youth: theoretical and practical aspects. Insight: the psychological dimensions of society, 5, 117-131. DOI: 10.32999/2663-970X/2021-5-8

Link article (Style DSTU 8302: 2015): Orap M. O., Kalba Ya. Ye. The research of the economic attitudes of Ukrainian youth: theoretical and practical aspects. Insight: the psychological dimensions of society, 2021, 5, 117-131. DOI: 10.32999/2663-970X/2021-5-8

UDC 316.64-057.87:330.16

\title{
The research of the economic attitudes of Ukrainian youth: theoretical and practical aspects
}

\author{
Дослідження економічних атитюдів української молоді: \\ теоретико-практичні аспекти
}

Received: March 15, 2021

Orap Maryna Olehivna

Doctor of Psychology,

Professor of the Department of Psychology

Ternopil Volodymyr Hnatiuk National

Pedagogical University, Ukraine

orap2003@ukr.net

ORCID 0000-0001-7598-8453

Kalba Yaroslava Yevhenivna

$\mathrm{PhD}$ in Psychology,

Senior Lecturer of the Department of Psychology

Ternopil Volodymyr Hnatiuk National

Pedagogical University, Ukraine yarka35@ukr.net

ORCID 0000-0003-0589-9126
Accepted: May 25, 2021

\author{
Орап Марина Олегівна \\ доктор психологічних наук, \\ професор кафедри психології \\ Тернопільський національний \\ педагогічний університет \\ імені Володимира Гнатюка, Україна \\ orap2003@ukr.net \\ ORCID 0000-0001-7598-8453 \\ Кальба Ярослава Євгенівна \\ кандидат психологічних наук, \\ доцент кафедри психології \\ Тернопільський національний \\ педагогічний університет \\ імені Володимира Гнатюка, Україна \\ yarka35@ukr.net \\ ORCID 0000-0003-0589-9126
}

\begin{abstract}
The article is a theoretical-empirical research of the economic attitudes of Ukrainian students. Theoretical analysis has allowed the authors to outline a conceptual research scope under the framework of behavioral economics, which regards economic attitudes as one of the types of social attitudes in the dispositional structure of personality. The purpose of the research is to conduct an empirical research of the features and patterns of economic attitudes of the student community; to consider a layered organization of economic
\end{abstract}

\begin{abstract}
Анотація
Стаття представляє теоретико-емпіричне дослідження економічних атитюдів українських студентів. Теоретичне аналізування дало змогу означити концептуальне поле дослідження в межах поведінкової економіки, що розглядає економічні атитюди як один з видів соціальних атитюдів у диспозиційній структурі особистості. Метою дослідження $€$ емпірично дослідити особливості та закономірності економічних атитюдів студентства; розглянути рівневу організацію економічних атитюдів
\end{abstract}


attitudes and partial elements of factor ideas; to analyze correlation relationships between economic attitudes and indices of students' economic status (the actual level of revenues and expenses). Research methods. The research and analysis of the features of economic attitudes of students have relied on O. Deineka and K. Zabielina survey for express diagnostics of the economic attitudes of young people. It has allowed the authors to characterize the scope of economic attitudes of a man in a holistic way, taking into account different spheres of economic behavior and socio-economic roles. Results. Based on quantitative and qualitative data processing, the research has established that the general level of economic attitudes of a study sample is above average. It has been found out that students' assessment of their financial situation as sufficient/insufficient does not depend on actual cash security but closely correlates with an overall index of economic attitudes $(r=.310 ; \mathrm{p} \leq .001)$. This fact proves that not a sum of money, but the very subjective assessment of its amount as sufficient/insufficient is instrumental in the attitude towards economic issues. The most significant factors influencing the economic attitudes of youth are the factors of "economic orientation activity" and "economic planning and financial optimism". Conclusions. Thus, a positive attitude to economic issues is peculiar to those students who strive to be financially aware, be in the loop of economic and financial life in a country and predict their financial situation and economic prospects.

Key words: attitudes, economic attitudes, students, financial situation, financial optimism.

\section{Introduction}

The volatility of the modern economic world and the global monetization of social space drastically alter the socio-economic conditions of human existence. Young people are the most vulnerable to globalization processes. The balancing act between material benefits and moral benchmarks, a frustrating need for competitiveness, demanding requirements to personality as an actor of economic relationship influence the history of economic socialization of the younger generation. Thus, it seems highly relevant to study the issues of economic attitudes of the youth in terms of the determination of economic well-being, identification of those factors which would shape the strategies of economic behavior, contribute to the development of economic awareness, та парціальні частки факторних представлень; проаналізувати кореляційні взаємозв'язки економічних атитюдів з показниками економічного становища студентів (реальним рівнем економічних доходів та витрат). Методи дослідження. Вивчення та аналіз особливостей економічних атитюдів студентської молоді проводились за питальником експрес-діагностики економічних атитюдів молоді О. Дейнеки іК. Забєліної, що дало змогу комплексно охарактеризувати поле економічних атитюдів людини, враховуючи різні сфери економічної поведінки та соціально-економічних ролей. Результати. На основі кількісної та якісної обробки даних встановлено, що загальний рівень економічних атитюдів у дослідженій вибірці вищий середнього. Досліджено, що оцінювання студентами власного фінансового стану як достатнього/недостатнього не залежить від реального грошового забезпечення, але тісно корелює із загальним показником економічних атитюдів ( $\mathrm{r}=.310 ; \mathrm{p} \leq .001)$. Це свідчить про те, що провідну роль у ставленні до економічних питань відіграє не кількість грошей, а саме суб'єктивне оцінювання їх кількості як достатньої/недостатньої. Найбільш значущими факторами, що впливають на економічні атитюди молоді, виявились фактори "орієнтувальної активності в економіці"та “економічного планування і фінансового оптимізму”. Висновки. Таким чином, позитивне ставлення до економічних питань характерне для тих студентів, котрі намагаються бути фінансово обізнаним, бути в курсі подій економічного і фінансового життя в країні та прогнозують власне фінансове становище та економічні перспективи.

Ключові слова: атитюди, економічні атитюди, студенти, фінансовий стан, фінансовий оптимізм.

\section{Вступ}

Мінливість сучасного економічного світу, глобальна монетаризація соціального простору докорінно змінюють соціально-економічні умови людського існування. Найбільш вразливою до глобалізаційних процесів стає молодь. Балансування між матеріальними благами і моральними орієнтирами, фруструюча потреба конкурентоспроможності, зростаючі вимоги до особистості як суб’єкта економічних взаємин, впливають на характер протікання економічної соціалізації підростаючого покоління. Відтак, вельми актуальним видається вивчення питання економічних

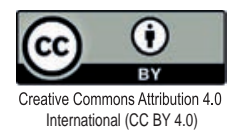


successful economic adaptation without depersonalization, losing personal qualities, declining life quality.

Foreign psychology traditionally considers the concept "attitude" as an organized system of convictions about an object or a situation, which determines a person's tendency to act in a particular way (Rokeach, 1986). In domestic psychology, studies rely on the classical understanding of an attitude - which was introduced by D. Uznadze - as personal modus, readiness to carry out an activity in a certain way. The modern thesaurus of psychological science also confirms the use of the concept "mental set" and English loan translation "atytiud" (attitude). I. Savka's thorough analysis of the studies devoted to the issues of attitude has made it possible to conclude that "ideas about "basic attitudes" by V. Yadov meet the concepts of "relation" by V. Miasyshchev, "orientation" by L. Bozhovych, "a fixed attitude that gains a great personal focus" by D. Uznadze. However, the system of value-based orientations meets the concepts of "an integral (global) attitude by D. Uznadze" (Savka, 2009). Modern English-language scientific literature interprets attitude as "an internal tendency", which is both a viewpoint and evaluative regard expressing this viewpoint (Eagly \& Chaiken, 2007). Keeping in mind the English term "attitude" includes not only a system of beliefs and relations but also a particular readiness to act in a certain way (one that has close meaning to the term "mental set" in domestic psychology), the authors have chosen the mentioned term to carry out the study of features of the economic attitudes of Ukrainian youth.

It is traditionally highlighted three components in the structure of attitudes: cognitive (realization of the object of social attitude); affective (emotional evaluation of the object, expression of sympathy or empathy to it) and connotative component (consistent behavior towards the object (Smith, 1986)). Contemporary scientists share the opinion that these components are closely interrelated (Huskinson et al., 2006) and sometimes can enter into controversial interrelations with each other (Conner et al., 2002).

In modern domestic psychology, the issue of attitudes is studied within the conceptual scope of value-based orientations which, according to атитюдів молоді в детермінації економічного благополуччя, виявлення тих факторів, які б визначали спрямованість стратегій економічної поведінки, сприяли розвитку економічної свідомості, успішній економічній адаптації без знеособлення, втрати особистісних чеснот, зниження якості життя.

У зарубіжній психології поняття "атитюд" (attitude) традиційно розглядають як організовану систему переконань щодо об’єкта або ситуації, яка визначає схильність людини діяти певним чином (Rokeach, 1986). У вітчизняній психології дослідження відштовхуються від класичного розуміння установки як модусу особистості, готовності виконувати діяльність певним чином, введеного ще Д. Узнадзе. Сучасний тезаурус психологічної науки засвідчує також використання понять“настанова” та англомовної кальки “атитюд”. Зроблений I. Савкою грунтовний аналіз досліджень, присвячених проблемам установки, дав змогу зробити висновок про те, що "уявлення про“базові соціальні установки” В. Ядова відповідає поняттям "ставлення" за В. Мясищевим, спрямованість” за Л. Божович, “фіксована установка, яка набуває великої особистісної ваги" за Д. Узнадзе. Система ціннісних орієнтацій, натомість, відповідає поняттям "цілісної (глобальної) установки” за Д. Узнадзе” (Савка, 2009). У сучасній англомовній науковій літературі в змісті attitude розрізняють "внутрішню тенденцію” як позицію та оціночне ставлення, що виражає цю позицію (Eagly \& Chaiken, 2007). Беручи до уваги те, що англомовний термін “attitude" передбачає врахування не лише системи переконань і ставлень, але і певну готовність діяти певним чином (те, що у вітчизняній психології ближче за значенням до терміну “установка"), ми обираємо саме цей термін (у його україномовній транскрипції) для реалізації нашого дослідження особливостей економічних атитюдів української молоді.

У структурі атитюдів традиційно увиразнюють три компоненти: когнітивний (усвідомлення об'єкта соціальної установки); афективний (емоційна оцінка об'єкта, виявлення почуття симпатії або антипатії до нього) і конативний компонент (послідовна поведінка по відношенню до об'єкта (Smith, 1986). Сучасні

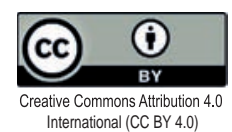


scientists, are characterized by vigorous changes and significant transformations at the present stage and, at the same time, act as subjective factors regulating the economic activity of young people (Husak, 2012). By conducting a thorough comparative retrospective analysis of the valuebased orientations of the youth, N. Levkovska established the tendencies of changing of value-based strengths of the youth: the privilege of individualism, a focus on personal-family relations, freedom from community lifestyle (Levkovska, 2006). As 0. Balakirieva states, "the changes which have taken place in value labor orientations express the need to shape a new motivation mechanism that would encourage creative activity and initiative of young people, new forms of professional self-realization (Balakirieva, 2020: 22). Value-based orientations of a person have close relations with the level and quality of his economic activity. Therefore, if one refers to the economic value orientations and attitudes of the youth, 0 . Doronina \& 0 . Somyk have found out that young people are the most vulnerable category from the perspective of the power of influence of the economy on value orientations (Doronina, 2020). The authors specify "individual economic ideas and behavior of a person is an outcome of the formed orientations and attitudes; thus, value orientations have a direct influence on the economic conduct, economic activity of any member of modern society and the youth in particular" (Doronina, 2020). The above determines the relevance to study the economic attitudes of modern youth and creates a necessary theoretical base of the current research.

Hypothesis. The authors assume that economic attitudes are interdependent with students' assessment of their financial situation. The research findings make it possible to outline general tendencies of the economic attitudes of Ukrainian students.

The purpose of the research is to study patterns and features of the economic attitudes of modern Ukrainian youth exemplified by students. The purpose of the research is clarified in the following scientific-research tasks:

1. To conduct an empirical research of features and patterns of the economic attitudes of the student community. дослідники поділяють думку, що ці компоненти тісно взаємопов'язані (Huskinsonetal., 2006), а іноді можуть вступати в суперечливі взаємини один з одним (Conneretal., 2002).

У сучасній вітчизняній психології питання атитюдів вивчається у концептуальному поліпроблеми ціннісних орієнтацій, які, як зазначають дослідники, на сучасному етапі розвитку суспільства характеризуються стрімкими змінами і значними трансформаціями та, водночас, виступають суб'єктивними чинниками регулювання економічної активності молоді (Гусак, 2012). Здійснивши грунтовний порівняльний ретроспективний аналіз ціннісних орієнтацій молоді, Н. Левковська визначила тенденції змін ціннісних переваг сучасної молоді - перевага індивідуалізму, акцент на особистісно-сімейних інтересах, відмова від колективістського способу життя (Левковська, 2006). I, як зазначає О.Балакірєва, “зміни, що відбулися в ціннісних трудових орієнтаціях, показують необхідність формування нового механізму мотивації, який стимулював би творчу активність та ініціативу молоді, нові форми самореалізації в праці" (Балакірєва, 2002: 22). Ціннісні орієнтації людини мають тісний зв'язок з рівнем та якістю її економічної активності. Відтак, якщо говорити про економічні ціннісні орієнтації та настанови молоді, то, як виявили 0. Дороніна і О. Сомик, саме молодь $є$ найбільш вразливою категорією з точки зору сили впливу економіки на ціннісні орієнтації (Дороніна, 2020). Як зазначають автори, “індивідуальні економічні уявлення та поведінка людини $\epsilon$ продуктом сформованих ціннісних орієнтацій та настанов, отже ціннісні орієнтації здійснюють безпосередній вплив на економічну поведінку, економічну активність будь-якого члена сучасного суспільства та молоді зокрема" (Дороніна, 2020).Це зумовлює актуальність дослідження економічних атитюдів сучасної молоді та створює необхідну теоретичну базу нашого дослідження.

Гіпотеза. Автори припускають, що економічні атитюди знаходяться у взаємозалежності 3 оцінюванням студентами власного фінансового стану. Результати дослідження дадуть змогу виокремити загальні тенденції економічних атитюдів українського студентства.

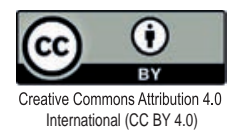


2. To consider a layered organization of the economic attitudes and partial elements of the factor ideas.

3. To analyze correlation relationships between the economic attitudes and indicators of students' economic situation (the actual level of revenues and expenses).

\section{Research methodology.}

The term "economic attitudes" has various scientific interpretations and is regarded in various contexts: for instance, as a subjective position (disposition) on making economic decisions to satisfy one's material needs (Denegri, 2011); as a particular construction the structure of which involves convictions, abilities and skills, which permit a person to percept an economic environment in the narrow and global aspects and render effective decisions according to one's economic resources (Soper et al., 1988). The cognitive component of economic attitudes depends on a specific level of a person's knowledge of economics. (Yahaya et al., 2019). In addition, there were established positive correlations between labor values and attitude to money (Furnham, 1996), between economic attitudes and social attitudes and people's attitudes (Lönnqvist \& Kivikangas, 2019). The samples of grownups (Von Stumm et al., 2013) and young people (Soper et al., 1988) proved that economic abilities and money attitudes influence the readiness to risk or overcome financial obstacles. Consequently, this research has relied on the methodological principles of behavioral economics (Morris, 2006), which considers economic attitudes as a strategy of a person's economic conduct in situations of various economic character (Kirchmaier et al., 2018), including an effective (positive) use of money and other resources (Deineka, Zabelyna, 2018).

Survey sample. 202 undergraduate students of Ternopil Volodymyr Hnatiuk National Pedagogical University(from the faculties offoreign languages, history, physics and mathematics, engineering education) took part in the research. The age of respondents, among which are 89 men and 113 women, is $17.48 \pm .62(\mathrm{M} \pm \mathrm{SD})$. According to comparison results of the male
Мета дослідження: дослідити закономірності та особливості економічних атитюдів сучасної української молоді на прикладі студентства. Мету дослідження конкретизовано у таких науково-дослідницьких завданнях:

1. Емпірично дослідити особливості та закономірності економічних атитюдів студентства.

2. Розглянути рівневу організацію економічних атитюдів та парціальні частки факторних представлень.

3. Проаналізувати кореляційні взаємозв'язки економічних атитюдів 3 показниками економічного становища студентів (реальним рівнем економічних доходів та витрат).

\section{Методологія дослідження.}

Поняття "економічні атитюди" має різні наукові тлумачення і розглядається у різних контекстах. До прикладу: як суб'єктивна позиція (диспозиція) щодо прийняття економічних рішень з метою задоволення власних матеріальних потреб (Denegri, 2011); як певна конструкція, до структури якої входять переконання, здібності та навички, що дозволяють людині розуміти економічне середовище у вузькому та глобальному аспектах i приймати ефективні рішення відповідно до власних економічних ресурсів (Soperetal., 1988). Когнітивний компонент економічних (фінансових) атитюдів забезпечується та залежить від певного рівня економічних знань особистості (Yahayaetal., 2019). Зокрема, виявлено позитивні кореляції між цінностями роботи та ставленням до грошей (Furnham, 1996), між економічними атитюдами та соціальними атитюдами і ставленнями людей (Lönnqvist\&Kivikangas, 2019). Доведено, що економічні здібності та грошові атитюди впливають на готовність ризикувати аби здолати фінансові труднощі у вибірках дорослих (VonStummetal., 2013) та молоді (Soperetal., 1988). Відтак, наше дослідження здійснено на методологічних засадах behavioraleconomic (Morris, 2006), в межах якої економічні атитюди розглядаються як стратегія економічної поведінки людини у ситуаціях різного економічного характеру (Kirchmaier etal., 2018), включно 3 ефективним (успішним) 
and female samples upon Student's t-test $(\mathrm{t}=.43<$ $\mathrm{t}$ critical $=3.34, \mathrm{n}=202, \alpha=.001$ ), there are no statistically significant differences between men and women. The beforementioned means that gender in the relevant respondent sample doesn't essentially influence the indices of economic attitudes; thus, the authors haven't referred to this index to calculate and interpret the results.

Procedure and tools. The research and analysis of the features of students' economic attitudes have relied on 0. Deineka \& K. Zabielina (Deineka \& Zabielina, 2018) survey for express diagnostics of the economic attitudes of the youth. The survey holistically characterizes a scope of economic attitudes of a person, taking into account different spheres of economic behavior and socio-economic roles: a proprietor (an attitude towards money, property, and investment behavior), consumer, entrepreneur and employee (Deineka \& Zabielina, 2018). The survey consists of 17 questions that deal with the economic attitudes in different spheres of economic reality. Each question is evaluated according to Likert-type scale ranging from 1 point (strongly disagree) to 7 points (strongly agree). Therefore, the maximum amount of survey points is 119 and the minimum 17 points. The survey's authors singled out a factor structure of the inventory that allows calculating extra 4 factors which describe the features of economic attitudes: 1) the factor of economic orientation activity; 2) the factor of economic planning and financial optimism; 3) the factor of trust / distrust in economic institutions; 4) the factor of socio-economic comparison.

Statistical analysis. The results of the empirical study have been processed using the methods of mathematical statistics: the Pearson correlation coefficient, the mean and standard deviation $(\mathrm{M} \pm$ SD) under the statistical program "MS Excel".

\section{Research results}

Content analysis of the indices of students' financial situation and economic attitudes

In addition to O. Deineka and K. Zabielina method for express diagnostics of the economic attitudes of the youth, the authors have held a survey (a written questionnaire) to clarify використанням грошей та інших ресурсів (Дейнека, Забелина, 2018).

Вибірка дослідження. У дослідженні взяли участь202студенти бакалаврату Тернопільського національного педагогічного університету імені В.Гнатюка (факультету іноземних мов, історичного, фізико-математичного, інженерно-педагогічного факультетів). Вік респондентів $17.48 \pm .62(\mathrm{M} \pm \mathrm{SD})$, з яких 89 чоловіки і 113 жінки.Згідно з результатами порівняння вибірки чоловіків і жінок за t-критерієм Стьюдента $(\mathrm{t}=.43<\mathrm{tcritical}=3.34, \mathrm{n}=$ $202, \alpha=.001$ ) статистично значимих відмінностей у показниках чоловіків і жінок не виявлено. Це означає, що ґендер у даній вибірці респондентів істотно не впливає на показники економічних атитюдів, тому далі ми не враховували цей показник для обчислень та інтерпретації результатів.

Процедура та інструменти. Вивчення та аналіз особливостей економічних атитюдів студентської молоді проводились за питальником експрес-діагностики економічних атитюдів молоді О. Дейнеки і К. Забєліної (Дейнека, Забелина, 2018). Цей опитувальник комплексно характеризує поле економічних атитюдів людини, враховуючи різні сфери економічної поведінки та соціально-економічних ролей: власника (ставлення до грошей, до власності, інвестиційна поведінка), споживача, підприємця і працівника (Дейнека, Забелина, 2018). Опитувальник містить 17 питань, що стосуються економічних атитюдіву різних сферах економічної реальності. Кожне питання оцінюється за 7-бальною шкалою Лайкерта, де 1 бал - "абсолютно не згідний", 7 балів “повністю згідний”. Відтак, максимальна сума балів за опитування - 119 балів, мінімальна 17 балів. Авторами питальника виокремлено факторну структуру опитувальника, що дає змогу додатково обчислити 4 фактори, які описують особливості економічних атитюдів: 1) фактор орієнтувальної активності в економіці; 2) фактор економічного планування і фінансового оптимізму; 3) фактор довіри/ недовіри економічним інститутам; 4) фактор соціально-економічного порівняння.

Статистичне аналізування. Результати емпіричного дослідження оброблялись за 
their financial situation and economic activity. Therefore, an answer to the question "What amount of money do you spend on your needs per month?" provides information about the actual expenses and approximate revenue of respondents (the respondents have been put flesh on the fact that "one's needs" are all expenses per month). The authors notionally called this index "objective financial situation" (OFS) while processing the results. It has been established the majority of young people spend on their needs from 1000 to 2000 UAH (39.10\%) per month, $1000 \mathrm{UAH}$ - 36.14\%, from 2000 to $4000 \mathrm{UAH}-$ $19.81 \%$, from 4000 to $6000-3.96 \%$, and more than $6000 \mathrm{UAH}$ per month $-0.99 \%$ of respondents. Given that a minimum salary is of about $6000 \mathrm{UAH}$, the above sums do not objectively seem sufficient.

Thus, the question "How would you evaluate the sufficiency/insufficiency of your revenues?" has been aimed at identifying respondents' subjective assessment of their revenues - this index has been notionally called "subjective financial situation" (SFS). Following the results of the question, the vast majority of respondents $(52.97 \%)$ consider their revenues to be more likely sufficient than insufficient, $18.81 \%$ consider them to be almost sufficient, $16.34 \%$ - highly sufficient. $11.88 \%$ (24 respondents) consider their revenues to be insufficient. At the same time, a bulk of respondents' revenues is parental help. $67.32 \%$ of respondents mentioned them as the primary source of income, $13.32 \%$ consider the scholarship to be the primary income, $5.44 \%$ have a stable job, and $4.95 \%$ consider occasional earnings to be the primary income (one-time earnings, freelance payments, etc.). Five respondents mark a lack of revenues, and one respondent specifies that he lives off the savings made during summer employment. Moreover, $38.61 \%$ of respondents state that they have additional income in the form of a regular job, temporary earnings, irregular money payments etc. Such brief information about the objective and subjective indices of the financial situation of the respondent students has allowed the authors to conduct a comparative analysis of attitudes to the economic sector of life.

The survey for the express diagnostics of economic attitudes (EA) has found the mean of economic attitudes is $74.614 \pm 8.92(\mathrm{M} \pm \mathrm{SD})$. допомогою методів математичної статистики кореляційний аналіз за Пірсоном, середнє значення та середнє квадратичне відхилення $(\mathrm{M} \pm \mathrm{SD})$ у статистичній програмі "MS Excel”.

\section{Результати дослідження \\ Контент аналізування показників фінансового стану та економічних атитю- дів студентів}

Додатково до методики експрес-діагностики економічних атитюдів молоді О. Дейнеки, К. Забєліної було проведено опитування (письмове анкетування) на предмет вияву їх фінансового становища та економічної діяльності. Так, зокрема, відповідь на питання "Яку суму в місяць ви витрачаєте на свої потреби?" дає відомості про реальні витрати i приблизні доходи респондентів (було проведено роз'яснювальну бесіду з уточнення питання про те, що “власні потреби"- це усі видатки за місяць). Цей показник при обробці результатів ми умовно назвали “об'єктивний фінансовий стан” (ОФС). Виявилось, що найбільша кількість молоді витрачає на свої потреби в місяць від 1000 до 2000 грн (39.10\%), до 1000 грн - 36.14\%, від 2000 до 4000 грн - 19.81\%, від 4000 до $6000-3.96 \%$ та більше 6000 грн в місяць - 0.99\% респондентів. Якщо враховувати, що мінімальна заробітна платня в Україні встановлена на рівні 6000 грн, то об'єктивно ці суми видаються не надто достатніми.

Відтак, питання "Як ви оцінюєте достатність/недостатність ваших доходів" мало на меті виявити суб'єктивну оцінку респондентами власних доходів, і цей показник ми умовно назвали “суб”єктивний фінансовий стан” (СФС). За результатами цього питання переважна більшість респондентів (52.97\%) вважає свої доходи частіше достатніми, ніж недостатніми, $18.81 \%$ вважають їх майже достатніми, $16.34 \%$ - навіть більш, ніж достатніми. I лише 11.88\% (24 респонденти) вважають свої доходи недостатніми. При цьому, основну частину доходів респондентів складає допомога батьків.67.32\% респондентів назвали їх основним джерелом свої доходів, $13.32 \%$ - вважають стипендію основним доходом, $5.44 \%$ - мають постійне місце роботи,

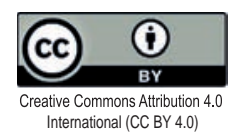


This has allowed defining the levels manifesting economic attitudes: high level ranges from $119-$ 84 points (15.84\%), medium level - $83-66$ points (70.30\%), low level - $65-17$ points $(13.86 \%)$. A high level of economic attitudes is conveyed by high scores upon all questions and characterized by active economic orientation, a positive attitude towards economic issues, financial optimism, confidence in economic institutions, endeavors to achieve economic well-being.

The factor of "economic orientation activity" (F1) encompasses the questions which touch upon a person's endeavors to be in the loop of economic and financial life in a country, be interested in prices and price setting, be financially aware, compare the prices, brands, shops and chose the most relevant ones. The questions make it possible to identify the level of the search activity of the subject as a buyer, consumer of financial services. Such an activity is obviously maintained by high self-esteem of financial literacy and value of one's economic achievements. In the study sample, the mean of this factor is $17.90 \pm 3.58(\mathrm{M} \pm \mathrm{SD})$. Consequently, by identifying the levels of manifestation of this factor, the values have distributed as follows: high level: $28-22$ points, medium level $-21-14$ points, low level - $13-4$ points. According to the results of the research a high level of orientation activity is peculiar to $15.34 \%$ of respondents, medium level $73.27 \%$ and low - for $11.39 \%$ of respondents.

The factor of "economic planning and financial optimism" (F2) expresses a person's attitude towards predicting own financial situation and economic perspectives, maintains attitudes towards savings and relations with money. The question "whether other people treat me as financially aware" maintains the reflection of personal knowledge and skills in the financial realm. In the sample "students", the mean of this factor is $24.59 \pm 3.75(\mathrm{M} \pm \mathrm{SD})$. This has allowed identifying the level of optimism manifestations in the financial area and economic planning: high level - 35 - 29 points - is peculiar to $13.86 \%$ of respondents, medium level - 28 - 21 points$74.26 \%$, low level $-20-5$ points $-11.88 \%$ of respondents.

The separation of factor "trust/distrust in economic institutions" (F3) within the system а 4.95\% - основним доходом вважають нерегулярні заробітки (одноразових заробітків, грошових виплат за фріланс тощо). П'ятеро респондентів зазначили відсутність доходів, а один зазначив, що живе за рахунок накопичень, зроблених під час роботи в літній період. При цьому, 38.61\% опитаних зазначили, що мають додатковий дохід у вигляді постійної роботи, тимчасових заробітків, нерегулярних грошових виплат тощо. Такі короткі відомості про об'єктивні та суб'єктивні показники фінансового становища опитаних студентів дали нам змогу здійснити порівняльний аналіз ставлення до економічної сфери життя.

За результатами опитувальника експрес-діагностики економічних атитюдів (ЕA) визначено, що середнє значення економічних атитюдів знаходиться в межах $74.614 \pm 8.92$ $(\mathrm{M} \pm \mathrm{SD})$. Це дало змогу визначити рівні вияву економічних атитюдів: високий рівень знаходиться в межах 119 - 84 балів (15.84\%), середній рівень- 83 - 66 балів (70.30\%), низький рівень- 65 - 17 балів (13.86\%). Високий рівень економічних атитюдів виявляється високими балами за усіма питаннями і характеризується активним орієнтуванням в економіці, позитивним ставленням до економічних питань, фінансовим оптимізмом, довірою до економічних інститутів наявністю прагнень досягнути економічного благополуччя.

Фактор "орієнтувальної активності в економіці"(Ф1) об’єднує у собі питання, які стосуються намагання людини бути у курсі подій економічного і фінансового життя в країні, цікавитись цінами та ціноутворенням, бути фінансово обізнаним, порівнювати ціни, бренди, магазини та обирати найбільш відповідні. Ці питання дозволяють виявити рівень пошукової активності суб'єкта як покупця, як споживача фінансових послуг. Така активність, вочевидь, підтримується високою самооцінкою фінансової грамотності і цінністю власних економічних досягнень. У досліджуваній вибірці середнє значення цього фактора $17.90 \pm 3.58$ (M \pm SD). Відтак, при визначенні рівнів вияву цього фактора значення розподілились таким чином: високий рівень: 28 - 22 бали, середній рівень - 21 - 14 балів, низький рівень - 13 - 4 балів. За результатами 
The research of the economic attitudes of Ukrainian youth: theoretical and practical aspects

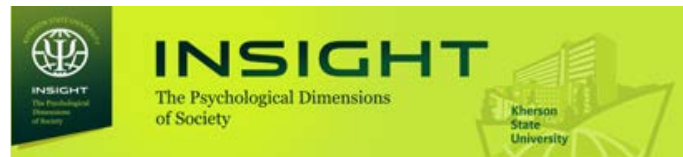

of economic attitudes is caused by the need to take into account the opposition of trust in the banking sector and entrepreneurship, on the one hand, to dissatisfaction with one's consumer opportunities, a lack of desire and willingness to invest money, on the other hand. According to the concept of the survey's developers (Deineka \& Zabielina, 2018), the subjects are satisfied with their consumer opportunities and, at the same time, they have positive investment and entrepreneurial attitudes. They are manifested in the negative answers to the question "only a person who knows how to deceive can become a successful entrepreneur" and "I believe that there is no point in making bank deposits because inflation "eats up" all interest" and in affirmative answers to the questions which elucidate investment activity and readiness to risk. The mean upon this factor is $15.09 \pm 2.90$ ( $\mathrm{M} \pm \mathrm{SD})$. Thus, the high level of the factor "trust / distrust in economic institutions" (28 - 18 points) is peculiar to $16.34 \%$ of respondents, medium level (17 12 points) - 74.26\%, low level (11 - 4 points $)-$ $9.40 \%$ of respondents.

The psychological aspects of economic attitudes also consider the aspects of treating people who achieved success in entrepreneurial and financial sectors, which are closely associated with a sense of guilt over one's economic opportunities or achievements (that can become an essential factor of economic success/failure). The attitudes towards competition, active adaptation to market conditions and restrictive economic behavior (associated with attitude "color inside the lines", "blend in") are clarified through the questions gathered within the factor of "socio-economic comparison" (F4). The survey findings upon this factor show $17.05 \pm 2.77(\mathrm{M} \pm \mathrm{SD})$. The high level of the manifestation of this factor is peculiar only to $9.9 \%$ of respondents ( $28-21$ points), medium level $-82.67 \%$ ( 20 - 14 points), low level $-7.43 \%$ (13 - 4 points).

\section{Correlation analysis of the indices of economic attitudes and financial situation of the students.}

The weightiest practical results of the research are identified through applying correlation analysis, the results of which are represented in table 1. дослідження виявлено, що високий рівень орієнтувальної активності характерний для $15.34 \%$ респондентів, середній $-73.27 \%$ і низький - для $11.39 \%$ респондентів.

Фактор "економічного планування і фінансового оптимізму" (Ф2) виявляє ставлення людини до прогнозування власного фінансового становища та економічних перспектив, актуалізує ставлення до накопичень і поведінки з грошима. Питання про те, "чи вважають інші люди мене фінансово грамотним" актуалізує рефлексію власних знань і умінь у фінансовій сфері. У вибірці “студентська молодь”середнє значення цього фактора становить $24.59 \pm 3.75(\mathrm{M} \pm \mathrm{SD})$. Це дало змогу визначити рівні вияву оптимізму у фінансовій сфері та економічному плануванні: високий рівень - 35 - 29 балів - характерний для $13.86 \%$ респондентів, середній рівень - 28 21 бал - 74.26\%, низький рівень - 20 - 5 балів $11.88 \%$ респондентів.

Виокремлення фактору “довіри/недовіри економічним інститутам” (ФЗ) у системі економічних атитюдів зумовлено необхідністю врахування протиставлення довіри до банківської сфери і підприємництва, з одного боку, і незадоволеності власними споживчими можливостями, відсутністю бажання і готовності вкладати гроші, з іншого боку. Відповідно до концепції розробників опитувальника (Дейнека, Забєліна, 2018), суб'єкти, задоволені своїми споживчими можливостями,водночас мають позитивні інвестиційні та підприємницькі установки. Вони виявляються через заперечні відповіді на питання "успішним підприємцем може стати лише людина, здатна обманювати” і “я вважаю, що робити банківські вклади не має змісту, оскільки усі відсотки "з'їдає" інфляція"; та через позитивні відповіді на питання, які виявляють інвестиційну активність і готовність до ризику. Середнє значення за цим фактором становить $15.09 \pm 2.90(\mathrm{M} \pm \mathrm{SD})$. Таким чином, високий рівень фактору “довіри/недовіри економічним інститутам” (28 - 18 балів) притаманний $16.34 \%$ респондентів, середній рівень (17 - 12 балів) - 74.26\%, низький рівень (11 - 4 бали) - 9.40\% респондентів.

Психологічні аспекти економічних атитюдів враховують також і аспекти ставлення до

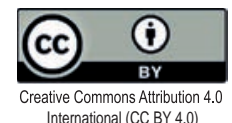


One can observe a lack of the correlation coherence between the actual level of revenues and expenditures of the respondents (OFS) and subjective evaluation of it (SFS) as to be sufficient/insufficient $(r=.063)$. This means that an attitude towards the level of one's financial situation in this sample doesn't depend on the actual amount of money that the respondents spend for their own needs.

However,thereisaclose, positiveand statistically significant correlation between respondents' subjective assessment of revenues and the overall index of economic attitudes $(r=.310 ; p \leq .001)$. This suggests the better and higher a person evaluates his financial situation, the most positive attitudes he has towards economic issues in his life. The above also proved by 0. Chykhantsova, who detected a close correlation relationship between the satisfaction with a financial situation and the level of life satisfaction on the whole (Chykhantsova, 2020). It stands to reason that individual factors of the general economic attitudes show correlation relationships with SFS as well; moreover, this relationship is the most significant between SFS and F1 $(r=.228$; $\mathrm{p} \leq .01)$ and SFS and F2 ( $\mathrm{r}=.219 ; \mathrm{p} \leq .01)$; it is lesser between SFS and F3 ( $\mathrm{r}=.166 ; \mathrm{p} \leq .05)$ and F4 $(\mathrm{r}=.163$; $\mathrm{p} \leq .05)$. At the same time, there is a tendency that the actual financial situation (an amount of money) conveyed in the index "objective financial situation" (OFS) doesn't influence these

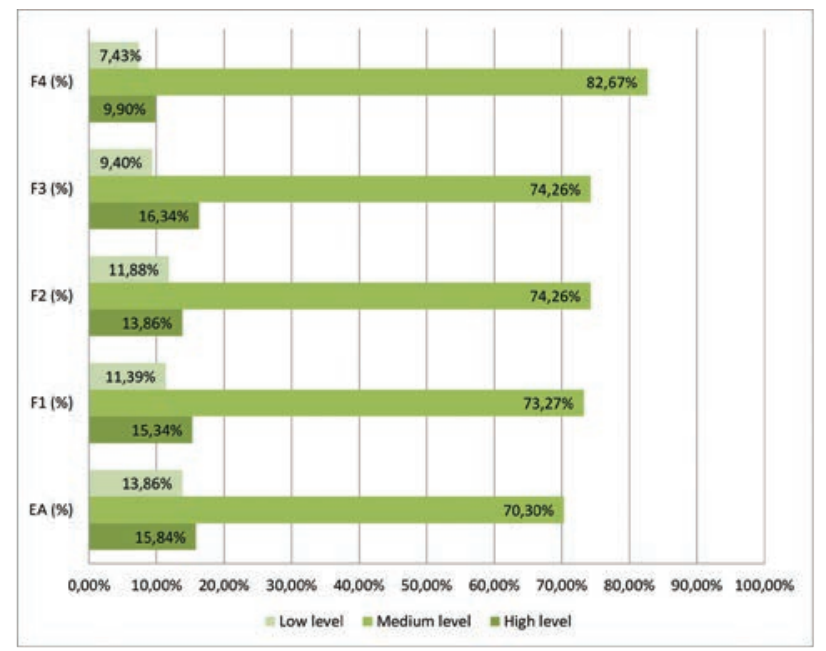

Fig. 1. Correlation of the levels manifesting economic attitudes and their individual factors людей, які досягнули успіху у підприємницькій та фінансовій сферах, що тісно пов'язані з почуттям провини за власні економічні можливості чи досягнення (що може стати істотним чинником економічного успіху/неуспіху). Установки стосовно конкуренції, активної адаптації до ринкових умов та на обмежувальну економічну поведінку (пов'язану з установкою "не виділятись", “бути як всі") виявляються за допомогою питань, зібраних у факторі "соціально-економічне порівняння" (Ф4). Результати опитування за цим фактором продемонстрували середнє значення $17.05 \pm$ $2.77(\mathrm{M} \pm \mathrm{SD})$. Високий рівень вияву даного фактору притаманний лише $9.9 \%$ респондентів (28 - 21 бал), середній рівень -82.67\% (20 14 балів), низький рівень - 7.43\% (13 - 4 бали).

Кореляційний аналіз показників економічних атитюдів та фінансового стану студентів.

Найбільш вагомі практичні результати здійсненого дослідження виявлено за допомогою кореляційного аналізу, результати якого представлені у таблиці 1.

Ми спостерігаємо відсутність кореляційного зв'язку між реальним рівнем доходів та витрат респондентів (ОФС), та його суб'єктивним оцінюванням (СФС) як достатнього/ недостатнього $(\mathrm{r}=.063)$. Це означає, що ставлення до рівня власного матеріального статку у даній вибірці не залежить від реальної кількості грошей, які витрачають респонденти на власні потреби.

Натомість простежуємо тісний позитивний статистично значущий кореляційний

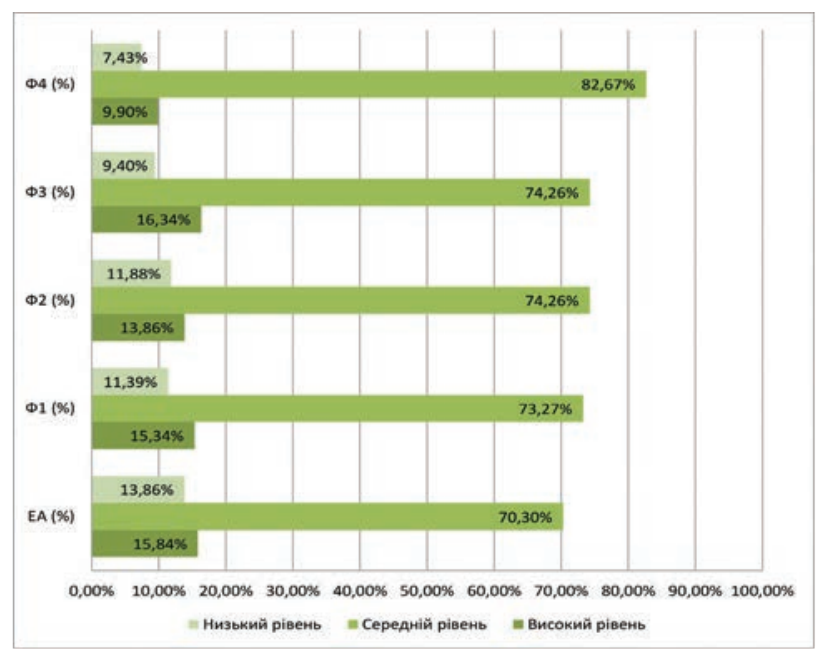

Рис 1. Співвідношення рівнів вияву економічних атитюдів та їх окремих факторів

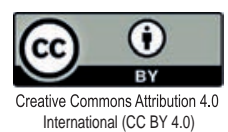


attitudes ( $\mathrm{r}=.107)$. As the research findings (Ma Feng at al., 2020) showed, the results can be partially explained by the fact that a subjective attitude of Ukrainian students towards their lives is based on such concepts as "hardiness" and "optimism", which are associated in Ukrainian mentality with resistance to obstacle crossing and faith in a better future.

There are mutual positive correlations almost between all factors of economic attitudes. F1 positively correlates with F2 $(\mathrm{r}=$.405) and F4 ( $\mathrm{r}=.247 ; \mathrm{p} \leq .001)$ that allows assuming a young person's striving to be aware of events of the economic life in the country, price setting, interest in understanding the mechanisms of advertising and marketing influences the success of prediction of one's financial situation and economic prospects. A lack of statistically significant correlations between $\mathrm{F} 1$ and F3 $(\mathrm{r}=.102)$ stresses that economic insights do not always contribute to the emergence of trust in economic institutions.

\section{Discussion}

Moreover, the positive correlation between $\mathrm{F} 2$ and F4 ( $\mathrm{r}=.294)$ allows highlighting a substantial impact of "other, others" on зв'язок між суб'єктивною оцінкою власних доходів та загальним показником економічних атитюдів респондентів ( $\mathrm{r}=.310 ; \mathrm{p} \leq .001)$. Це свідчить про те, що, чим краще і вище оцінює особистість власний фінансовий стан, тим більш позитивні атитюди вона має стосовно економічних питань власного життя. Це підтверджується і дослідженнями О. Чиханцової, яка виявила тісний кореляційний зв'язок між задоволеністю фінансовим станом та рівнем задоволення життям загалом (Chykhantsova, 2020). Цілком очікувано окремі фактори загальних економічних атитюдів також виявляють кореляційні зв'язки з СФС, причому найбільш значимий цей зв'язок між СФС і Ф1 (r = .228; $\leq$.01) та СФС і Ф2 ( $\mathrm{r}=.219 ; \mathrm{p} \leq .01)$; дещо менший між СФС і Ф3 $(\mathrm{r}=.166 ; \mathrm{p} \leq .05)$ та $\Phi 4(\mathrm{r}=.163 ; \mathrm{p} \leq .05)$. Водночас спостерігаємо тенденцію, що реальний матеріальний стан (кількість грошей), об'єднані у показнику “об”єктивний фінансовий стан” (ОФС) на ці ставлення не впливає $(\mathrm{r}=.107)$. Частково ці результати можуть бути пояснені тим, що, як продемонстрували результати дослідження (MaFengta ін., 2020), в основі суб'єктивного ставлення до власного життя українських студентів лежать такі концепти, як “життєстійкість" та “оптимізм", пов'язані в ментальності українця зі стійкістю до подолання перешкод та вірою у краще.

Table 1. Correlation matrix of the indices of a financial situation and economic attitudes

Таблиця 1. Кореляційна матриця показників фінансового стану та економічних атитюдів

\begin{tabular}{|c|c|c|c|c|c|c|c|}
\hline $\begin{array}{l}\text { Factors } \\
\text { Фактор }\end{array}$ & $\begin{array}{l}\text { OFS } \\
\text { OФC }\end{array}$ & $\begin{array}{l}\text { SFS } \\
\text { CФC }\end{array}$ & $\begin{array}{l}\text { EA } \\
\text { EA }\end{array}$ & $\begin{array}{l}\text { F1 } \\
\text { Ф1 }\end{array}$ & $\begin{array}{l}\text { F2 } \\
\text { Ф2 }\end{array}$ & $\begin{array}{l}\text { F3 } \\
\text { \$3 }\end{array}$ & $\begin{array}{l}\text { F4 } \\
\text { \$4 }\end{array}$ \\
\hline $\begin{array}{c}\text { OFS } \\
\text { OФC }\end{array}$ & & .063 & .107 & .107 & 113 & .107 & .034 \\
\hline $\begin{array}{l}\text { SFS } \\
\text { СФC }\end{array}$ & & & $.310^{* * *}$ & $.228^{* *}$ & $.219^{* *}$ & $.166^{*}$ & $.163^{*}$ \\
\hline $\begin{array}{l}\text { EA } \\
\text { yA }\end{array}$ & & & & $.710^{* * *}$ & $.774^{* * *}$ & $.490^{* * *}$ & $.550^{* * *}$ \\
\hline $\begin{array}{l}\mathrm{F} 1 \\
\Phi 1 \\
\end{array}$ & & & & & $.405^{* * *}$ & .102 & $.247^{* * *}$ \\
\hline $\begin{array}{l}\mathrm{F} 2 \\
\Phi 2 \\
\end{array}$ & & & & & & $.209^{* *}$ & $.294^{* * *}$ \\
\hline $\begin{array}{l}\text { F3 } \\
\text { Ф3 } \\
\end{array}$ & & & & & & & $.190^{*}$ \\
\hline $\begin{array}{l}\mathrm{F} 4 \\
\Phi 4 \\
\end{array}$ & & & & & & & \\
\hline
\end{tabular}

Notes: ${ }^{*}$ - statistically significant at $\mathrm{p} \leq .05 .{ }^{* *}-$ statistically significant at $\mathrm{p} \leq .01 .{ }^{* * *}-$ statistically significant at $\mathrm{p} \leq .001$.

Примітка: * - статистично значущий при $\mathrm{p} \leq .05 . * *$ - статистично значущий при $\mathrm{p} \leq .01$. ***_ статистично значущий при $\mathrm{p} \leq .001$.

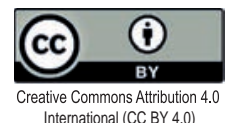


predicting economic prospects of young people. It is outlined the image of "a successful man" through the prism of the significance of financial status, economic ambitions, a value of independent economic achievements. To confirm the results of correlation analysis, the authors have used qualitative analysis of statistical data. The authors have considered the distribution of students' answers to the questions about the sight of respect to people who independently succeeded in life. Thus, $87.7 \%$ of respondents maximally assessed the manifestation of their respect and fascination with people who achieved economic success under their own steam by complementing their answers with theses like: "from time to time, I read the publications by Bill Gates, Steve Jobs, Elon Musk"; "the life and career journey of prominent figures is a pattern for my economic strategies" etc. One can regard the above findings, on the one hand, as a motivation strategy including a valuebased commitment to professional success, career progress, creative fulfillment, independent achievement and, on the other hand, as such which reflect a psychological type of ambitious young people who seek to reach a high financial status in the future, are optimistic about success, but don't have the relevant knowledge and financial tools, except saving money. The assumption is proved by the following empirical fact: $66.5 \%$ of respondents answered in the affirmative (20.2\% responded "more likely yes than no") that every person, regardless of his income level, should regularly save up for the future. One can interpret the creation of the so-called "rainy day fund" and thus economic behavior strategy as an echo of the archetype (collective) consciousness of the Ukrainian mentality since there were many "rainy days" in the national history.

The authors have put a special focus on the low correlation relationship between $\mathrm{F} 2$ and $\mathrm{F} 3(\mathrm{r}=.209)$ that can render immature, somewhat infantile, a contradictory attitude of young people to economic realities. By relying on qualitative analysis of statistical data, the authors state the following: most of the students are convinced that the level of their revenue will increase in the short term (59.1\% answered "yes"; $23.2 \%$ answered "more likely yes than no"); students are ready
Взаємні позитивні кореляції майже між усіма факторами економічних атитюдів. Ф1 позитивно корелює з Ф2 (r = .405) і Ф4 $(\mathrm{r}=.247 ; \mathrm{p} \leq .001)$, а це дозволяє припустити, що прагнення молодої людини бути обізнаною щодо подій економічного життя в країні, ціноутворення, інтерес до розуміння механізмів реклами і маркетингу впливає на успіх прогнозування власного фінансового становища та економічних перспектив. Відсутність статистично значимих кореляцій між Ф1 та Ф3 (r = .102) вказує на те, що не завжди орієнтування в економіці сприяє виникненню довіри до економічних інститутів.

\section{Дискусія}

Окрім цього, позитивна кореляція Ф2 з Ф4 $(\mathrm{r}=.294)$ дозволяє говорити про вагомий вплив "іншого, інших" на прогнозування власних економічних перспектив молоді. Увиразнюється образ “успішної людини" крізь призму значимості фінансового статусу, економічних амбіцій, цінності самостійних економічних досягнень. Для підтвердження результатів кореляційного аналізу скористаємось якісним аналізом статистичних даних. До уваги взято розподіл відповідей студентів на питання про вияв поваги до тих людей, які в своєму житті всього досягнули самостійно. Так, $87.7 \%$ респондентів максимально оцінили вияв своєї поваги і захоплення людьми, які самотужки досягнули економічного успіху, доповнюючи свої відповіді тезами на кшталт: “час від часу перечитую публікації Білла Гейтса, Стіва Джобса, Ілона Маска"; “життєвий і професійний шлях авторитетних людей є для мене взірцем власної економічної стратегії" тощо. Означені результати можемо розглядати, 3 однієї сторони, як мотиваційну стратегію 3 ціннісною орієнтацією на успіх в професійній сфері, кар'єрному рості, творчій реалізації, самостійному здобутку, а з іншої - як такі, що відображають психологічний тип амбіційної молоді, яка прагне здобути високий фінансовий статус у майбутньому, оптимістично налаштована з вірою в успіх, проте не володіє знаннями і фінансовими інструментами, як окрім заощаджувати кошти. Підтверджує наше припущення наступний емпіричний факт: $66.5 \%$ респондентів дали стверджувальну відповідь (20.2\% відповіли "скоріше так, чим ні") про те, що кожна людина, незалежно від свого рівня доходу, повинна регулярно робити заощадження на майбутнє. Створення такої собі "фінансової подушки безпеки", а відтак - економічної стратегії поведінки, можемо

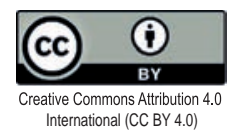


to display an economic activity, and even risk, invest in different economic projects $(42.9 \% \%$ answered "yes"; $17.7 \%$ answered "yes and no"); at the same time, young people hardly trust economic institutions (45,4\% answered "no"; $25.1 \%$ answered "yes and no"). The authors lean toward the idea that the above empirical facts reflect a certain perplexity, confusion of young people under the volatile conditions of both national and economic globalization processes; thus, they can't clearly perceive and outline the strategies of their economic success.

\section{Conclusions}

The general level of economic attitudes in the study sample is defined to be above-average that confirms a sufficient level of the economic optimism of Ukrainian students under modern economic realities.

The research considers close correlation relationships between the factor of "economic orientation activity" and the factors of "economic planning and financial optimism" and "socioeconomic comparison" as students' potential readiness and interest in economic knowledge, learning economic literacy. The authors have also drawn attention to a particular hierarchy of the correlation relationship between a subjective financial situation and presented factors of economic attitudes - the factors of economic orientation activity and economic optimist are most closely associated with the subjective economic situation.

It has been found out that students' evaluation of their financial status as sufficient/insufficient does not depend on actual cash security but closely correlates with economic attitudes. This fact shows that not an amount of money, but the very subjective assessment of their amount as sufficient/ insufficient plays a key role regarding economic issues. Therefore, financial optimism turns to be a significant factor in the economic attitudes of young people. Statistically significant positive correlation, which has been established due to the analysis of empirical data, between the subjective financial situation of students and their economic attitudes allows discussing economic attitudes as a component of the collective (group) consciousness of young people. розцінювати як певне відлуння архетипової (колективної) свідомості у ментальності українців, адже “чорних днів" в історії народу було достатньо.

Окремо зауважимо низький кореляційний зв'язок між Ф2 і Ф3 (r = .209), що може відображати незріле, певною мірою інфантильне, суперечливе ставлення молоді до економічних реалій. Опираючись на якісний аналіз статистичних даних, можемо констатувати: більшість студентів переконані, що рівень їхнього доходу найближчим часом зросте (59.1\% - відповіли “так”; $23.2 \%$ - відповіли “скоріше так чим ні"); студенти готові проявляти економічну активність, навіть ризикувати, інвестувати кошти у різні економічні проєкти (42.9\% - відповіли “так”; 17.7\% - відповіли “і так, і ні”); водночас молодь не зовсім довіряє економічним інститутам $(45.4 \%$ відповіли “ні"; 25.1\% - відповіли “і так, і ні”). Схиляємось до думки, що окреслені емпіричні факти відображають певну розгубленість, спантеличеність молоді у нестабільному полі як національних, так і глобалізаційних економічних процесів, а відтак - нездатну чітко усвідомлювати та окреслювати стратегії власного успіху в економічній сфері.

\section{Висновки}

Загальний рівень економічних атитюдів у дослідженій вибірці визначено як вищий середнього, що у сучасних економічних реаліях свідчить про достатній рівень економічного оптимізму українських студентів.

Тісні кореляційні зв'язки між фактором “орієнтувальної активності в економіці" та факторами "економічного планування та фінансового оптимізму" та "соціально-економічного порівняння" розглядаємо як потенційну готовність і запит студентів до знань економічного спрямування, навчанню фінансовій грамотності. Також звертаємо увагу на певну ієрархічність кореляційного зв' язку між суб'єктивним фінансовим становищем і представленими факторами економічних атитюдів - найбільш тісно пов'язані з суб'єктивним економічним станом фактори орієнтувальної активності в економіці та економічного оптимізму.

Виявлено, що оцінювання студентами власного фінансового стану, як достатнього/ недостатнього, не залежить від реального грошового забезпечення, але тісно корелює з економічними атитюдами. Це свідчить про те, що провідну роль у ставленні до економічних питань відіграє не кількість грошей, а саме суб'єктивне оцінювання їх кількості як 


\section{References}

Balakirieva, O. M. (2002). Transformation of value orientations in Ukrainian society. Ukrainian society, 2, 21-32. https://doi. org/10.15407/socium2007.02.007

Chykhantsova, O. A. (2020). A person's quality of life and features of its measurement. Insight: the psychological dimensions of society, 4, 11-28. DOI: $10.32999 / 2663-970 X / 2020-4-1$

Conner, M., \& Sparks, P. (2002). Ambivalence and attitudes. European Review of Social Psychology, 12, 37-70. DOI: $10.1080 / 14792772143000012$

Deineka, O. S, Zabielina, E. V. (2018). Results of development of a scale multifactor questionnaire for express diagnostics of economic attitudes. Psychological research, 1(58), 9.

Denegri, C., Sepúlveda, J., \& Godoy, B. (2011). Attitudes towards the purchase and consumption of pedagogy students and practicing teachers in Chile. Psicología desde el Caribe, 28 (1), 1-23.

Doronina, O. A. \& Somyk, O. M. (2020). Regulation of economic activity taking into account the value component of youth behavior. Efficient Economy, 4. DOI: 10.32702 / 2307-2105-2020.4.23

Eagly, A. H., \& Chaiken, S. (2007). The advantages of an inclusive definition of attitude. Social Cognition, 25(5), 582-602. DOI: 10.1521/soco.2007.25.5.582

Furnham, A. (1996). Attitudinal correlates and demographic predictors of monetary beliefs and behaviours. Journal of Organizational Behavior, 17(4), 375-388. DOI: 10.1002/(sici)10991379(199607)17:4

Gusak, N. E. (2012). Economic activity of youth. Youth in the conditions of formation of independent Ukraine (1991-2011). In S. Yu. Aksonova, O. L. Anufrieva, O. V. Belishev, E. I. Borodin, V. A. Golovenko, N. E. Gusak et all (Eds.). Annual report to the President of Ukraine, the Verkhovna Rada of Ukraine, the Cabinet of Ministers of Ukraine on the situation of youth in Ukraine. K.: VAITE, 77-108.

Huskinson, T. L. H., \& Haddock, G. (2006). Individual differences in attitude structure and the accessibility of the affective and cognitive components of attitude. Social Cognition, 24, 453-468. DOI: 10.1521/ soco.2006.24.4.453

Kirchmaier, I., Prüfer, P., \& Trautmann, S. T. (2018). Religion, moral attitudes and economic behavior. Journal of Economic Behavior \& Organization, 148, 282300, DOI: $10.1016 /$ j.jebo.2018.02.022.

Levkovskaya, N. (2006). Dynamics of value orientations of youth. Political Management, 1, 85-93.

Lönnqvist, J.-E., \& Kivikangas, M. (2019). Economic Attitudes, Social Attitudes and Their Psychological Underpinnings - A Study of the Finnish Political Elite. Frontiers in Psychology, 9 (10), 602. DOI: 10.3389/fpsyg.2019.00602 достатньої/недостатньої. Таким чином, фінансовий оптимізм виявляється значимим фактором економічних атитюдів молоді. Виявлений у результаті аналізу емпіричних даних статистично значимий позитивний кореляційний зв'язок між суб'єктивним фінансовим станом студентів та їх економічними атитюдами, дозволяє розглядати економічні атитюди як складову колективної (групової) економічної свідомості молоді.

\section{Список використаних джерел}

Rokeach M. (1986). The Nature of Attitudes. International Encyclopedia of the Social Sciences. Ed. D. L. Sills. Crowell.

Савка М. Аналіз теоретичних підходів до розуміння поняття "установка" в психологічній науці. Науковий вісник Львівського державного університету внутрішніх справ. № 1. 2009. С. 1-13.

Eagly A. H., Chaiken S. (2007). The advantages of an inclusive definition of attitude. Social Cognition, №. 25(5), P. 582-602. DOI: 10.1521/ soco.2007.25.5.582

Smith M.B. (1986). Attitude Change. International Encyclopedia of the Social Sciences.Ed. D. L. Sills. Crowell.DOI: 10.1146/annurev.psych.48.1.609

Huskinson T. L. H., Haddock G. (2006). Individual differences in attitude structure and the accessibility of the affective and cognitive components of attitude. Social Cognition, Vol. 24, P. 453-468. DOI: 10.1521/soco.2006.24.4.453

ConnerM., SparksP. (2002). Ambivalence and attitudes. European Review of Social Psychology, Vol. 12, P. 37-70. DOI: $10.1080 / 14792772143000012$

Гусак Н.Є. Економічна активність молоді. Молодь в умовах становлення незалежної України (1991-2011 роки). С.Ю. Аксьонова, О.Л. Ануфрієва, О.В. Бєлишев, Є.І. Бородін, B.А. Головенько, Н.Є. Гусак, та ін. Щорічна доповідь Президентові України, Верховній Раді України, Кабінету Міністрів України про становище молоді в Україні. К.: ВАІTЕ, 2012. C. $77-108$.

Левковська Н. Динаміка ціннісних орієнтацій молоді. Політичний менеджмент, № 1, 2006, C. 85-93

Балакірєва 0. М. Трансформація ціннісних орієнтацій в українському суспільстві. Український соціум. 2002. № 2. С. 21-32. https://doi.org/10.15407/socium2007.02.007

Дороніна О.А., Сомик О. М. Регулювання економічної активності з урахуванням ціннісної складової поведінки молоді. Ефективна економіка, № 4. 2020. DOI: $10.32702 / 2307-2105-2020.4 .23$

DenegriC., SepúlvedaJ., \&GodoyB. (2011). Actitudeshacia la compra y el consumo de estudiantes de

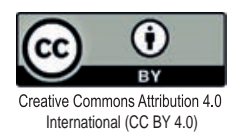


Ma, F., Shevchenko, R. P., \& Karhina, N. V. (2020). Student youth representation of psychological well-being: results of content analysis of works. Insight: the psychological dimensions of society, 3, 44-55. DOI: 10.32999/2663-970X/2020-3-3

Morris, A. (2006). Handbook of Contemporary Behavioral Economics. Foundations and Developments. Routledge Handbooks Online. DOI:10.4324/9781315703879

Rokeach, M. (1986). The Nature of Attitudes. International Encyclopedia of the Social Sciences. Ed. D. L. Sills. Crowell.

Savka, M. (2009). Analysis of theoretical approaches to understanding the concept of "Attitude" in psychological science. Scientific Bulletin of Lviv State University of Internal Affairs, 1, 1-13.

Smith, M., B. (1986). Attitude Change. International Encyclopedia of the Social Sciences. Ed. D. L. Sills. Crowell. DOI: 10.1146/annurev.psych.48.1.609

Soper, J. C., \& Walstad, W. B. (1988). Economic Attitudes of High School Students: New Norms for the Survey on Economic Attitudes. Theory and research in social education, 16 (4), 295-312. DOI: $10.1080 / 00933104.1988 .10505572$

Von Stumm S., Fenton O'Creevy M., \& Furnham A. (2013). Financial capability, money attitudes and socioeconomic status: Risks for experiencing adverse financial events. Personality and Individual Differences, 54(3), 344-349. DOI: 10.1016/j. paid.2012.09.019

Yahaya, R., Zainol, Z., Abidin, J. H. O. Z., \& Ismail, R. (2019). The Effect of Financial Knowledge and Financial Attitudes on Financial Behavior among University Students. International Journal of Academic Research in Business and Social Sciences, 9(8), 22-32. DOI: 10.6007/IJARBSS/v9-i8/6205 pedagogía y profesoresenejercicioen Chile [Attitudes towards the purchase and consumption of pedagogy students and practicing teachers in Chile]. Psicología desde el Caribe, № 28 (1), P. 1-23.

Soper J. C., Walstad W. B.(1988).Economic Attitudes of High School Students: New Norms for the Survey on Economic Attitudes. Theory and research in social education. Volume 16 (4), P. 295-312. DOI: 10.1080/00933104.1988.10505572

Yahaya R., Zainol Z., Abidin J. H. O. Z., \& Ismail R. (2019). The Effect of FinancialKnowledge and Financial Attitudes on Financial Behavior among University Students. International Journal ofAcademic Research in Business and Social Sciences, № 9(8), P. 22-32. DOI: 10.6007/IJARBSS/v9-i8/6205

Furnham A. (1996). Attitudinal correlates and demographic predictors of monetary beliefs and behaviours. Journal of Organizational Behavior, № 17(4), P. 375-388.DOI: 10.1002/(sici)10991379(199607)17:4

Lönnqvist J.-E. \& Kivikangas M. (2019). Economic Attitudes, Social Attitudesand Their PsychologicalUnderpinnings - A Study of theFinnish Political Elite. Frontiers in Psychology, № 9 (10), 602 p. DOI: $10.3389 /$ fpsyg.2019.00602

VonStummS., FentonO'CreevyM., Furnham A. (2013). Financial capability, money attitudes and socioeconomic status: Risks for experiencing adverse financial events. Personality and Individual Differences, 2013, №54(3), P. 344-349. DOI: 10.1016/j. paid.2012.09.019

Morris A. (2006). Handbook of Contemporary Behavioral Economics. Foundations and Developments. Routledge Handbooks Online. DOI:10.4324/9781315703879

Kirchmaier I., Prüfer, P. Trautmann, S. T. (2018). Religion, moral attitudes and economic behavior. Journal of Economic Behavior \& Organization, №148, P. 282-300, DOI: 10.1016/j.jebo.2018.02.022.

Дейнека О.С., Забелина Е.В. Результаты разработки шкального многофакторного опросника для экспресс-диагностики экономических аттитюдов. Психологические исследования. 2018. Т. 11, № 58. С. 9.

Chykhantsova O. A. (2020). A person's quality of life and features of its measurement. Insight: the psychologicaldimensions of society, № 4, P.11-28. DOI: $10.32999 / 2663-970 X / 2020-4-1$

Ma F., Shevchenko R. P.,\& Karhina N. V. (2020). Student youth representation of psychological well-being: results of content analysis of works. Insight: the psychological dimensions of society, № 3, P. 44-55. DOI: 10.32999/2663-970X/2020-3-3 